\title{
NAP Neuroprotective Peptide and its Analogs: Simultaneously Copper and Iron Binding and Reduction
}

\author{
ANCUTA-VERONICA LUPAESCU ${ }^{1}$, ION SANDU ${ }^{2,3}$, BRINDUSA ALINA PETRE ${ }^{1,4}$, LAURA ION ${ }^{1}$, CATALINA-IONICA CIOBANU5, \\ GABI DROCHIOIU1* \\ ${ }^{1}$ Alexandru Ioan Cuza University, Faculty of Chemistry, 11 Carol I Blvd., 700506 lasi, Romania \\ ${ }^{2}$ Alexandru Ioan Cuza University of lasi, Arheoinvest Interdisciplinary Platform, Scientific Investigation Laboratory, 11 Carol I \\ Blvd., 700506 lasi, Romania \\ ${ }^{3}$ Rmanian Inventors Forum, 3 Sf. Petru Movila Str., Bloc L11, III/3, 700089 Iasi, Romania \\ ${ }^{4}$ Center for Fundamental Research and Experimental Development in Translation Medicine -TRANSCEND, Regional Institute of \\ Oncology, 2-4 General Henri Mathias Berthelot, 700483 lasi, Romania \\ ${ }^{5}$ Alexandru Ioan Cuza University, Faculty of Chemistry, Research Department, 11 Carol I Blvd., 700506 lasi, Romania
}

\begin{abstract}
Neurodegenerative diseases, including Alzheimer disease, involve mechanisms such as protein aggregation, free radical generation and oxidative stress. Transition metals such as copper and iron were linked to neurodegenerative pathology. Their pathogenic role consists in generating different reactive oxygen species and damaging tissues or cells through the Fenton reaction. Abnormal metabolism of copper and iron can lead to several chronic pathogenesis. NAP is a small active fragment of activity-dependent neuroprotective protein essential for brain formation. NAP peptide showed neuroprotective proprieties against toxicity induced by the â-amyloid peptide, $N$-methyl-D-aspartate, electrical blockade, the envelope protein of the AIDS viruS, dopamine, $\mathrm{H}_{2} \mathrm{O}_{2}$, and nutrient starvation in cell culture. Therefore, we investigated here the interaction of $\mathrm{Cu}^{2+}$ and $\mathrm{Fe}^{3+}{ }^{2}$ ions with the NAP neuroprotective peptide and its analogs. With MALDI-ToF mass spectrometry, the formation of reduced metal-peptide complexes and the metal chelating properties of NAP-like neuroprotective peptides were highlighted.
\end{abstract}

Keywords: NAP peptide, neuroprotection, copper, iron, MALDI-ToF MS

All living beings operate with transition metals such as copper or iron in order to conduct their basic metabolic processes. Their importance can be noticed even at the synaptic level. For example, iron ions are needed for gene expression, the synthesis of neurotransmitters, myelination or respiratory management of the brain, while copperions are an important cofactor for antioxidant enzymes, neurotransmitter biosynthesis and mitochondrial respiration [1-3].

Neurodegenerative diseases are a critical worldwide health concern that affects the nervous system. These pathologies are associated with ageing and share features such as selective neuronal death, protein aggregation, oxidative stress, mitochondrial dysfunction, transition metal accumulation and inflammation [4]. However, evidence of a link between transition metals and neuronal death has been noticed in many neurodegenerative disorders such as Alzheimer's (AD), Parkinson's (PD) and Huntington's (HD) diseases [5-7]. Moreover, statistically significant differences between copper and zinc concentration in serum and saliva samples were observed at patients with oral cancer and oral potentially malignant disorders, suggesting a pathological role in those disease progression [8]. The accumulation of metals was observed in the brain of patients with neurodegenerative diseases. Thus, altered metal homeostasis can be one of the factors causing those disorders. Besides, redox active metals such as cooper and iron carry pro-oxidant properties that induce oxidative stress by generating reactive oxygen species (ROS) $[9,10]$. Most of the reactions involving redox active metals are related to Fenton chemistry that includes a series of reactions that initiates with hydrogen peroxide and leads to the formation of highly unstable radicals that affect biological macromolecules [5]. The disproportionate production of ROS species causes protein, DNA or phospholipids oxidations that mirrors in functional alterations [11, 12]. Thus, metal-binding proteins involved in the metal transportand distribution (copper transporter protein 1 and ATP7A, transferrin, transferrin receptor, DMT1) at synaptic level could have influence on the modified metal homeostasis in the brains of patients with neurodegenerative diseases [4].

Neuroprotective strategies against ROS-mediated damages in order to prevent oxidative stress and disease progression have been elaborated in numerous $A D$ researches [13-17]. Some of them successfully targeted mitochondria known as a major source of ROS. However, no crucial improvement was observed at AD patients [18].

Peptide-based drugs have emerged as a major class of therapeutics. NAP (NAPVSIPQ) is a small active fragment of activity-dependent neuroprotective protein (ADNP) essential for brain formation [19]. Studies involving cell culture reveled the neuroprotective proprieties of NAP peptide against toxicity associated with the beta-amyloid peptide, N-methyl-D-aspartate, electrical blockade, the envelope protein of the AIDS virus, dopamine, $\mathrm{H}_{2} \mathrm{O}_{2}$, nutrient starvation and zinc overload [20]. Also, NAP' can be delivered to the brain via intranasal or intravenous administration were it provides nerve cell protection atvery low concentrations providing new solutions for the formulation of neuroprotective drugs for the treatment of AD [21]. Studies involving metal-NAP interaction displayed abnormal metal reduction for copper and iron using cysteine-mutant NAPC $[22,23]$.

This study focuses on the interaction of $\mathrm{Cu}^{2+}$ and $\mathrm{Fe}^{3+}$ ions with neuroprotective peptide NAP and its analogs. An interesting phenomenon consisting in metal ion reduction 
followed by the formation of complexes with peptides was found within this research. MS analyses suggesta protective role of NAP-based peptides, since they are capable of capturing metal ions.

\section{Experimental part}

Materials and methods

Reagents

All chemicals were of analytical grade and were used as received without any further purification. All solutions were prepared using milliQ-grade water $(18.2 \mathrm{M} \Omega . \mathrm{cm}$, Millipore, Bedford, MA). Dimethylformamide (DMF) was purchased from Carl Roth $\mathrm{GmbH}$ (Karlsruhe, Germany) while dichloromethane (DCM) and diethyl ether were from Scharlab S.L. (Barcelona, Spain). Piperidine (PYP), 4methylmorpholine (NMM), triisopropylsilan (TIS), trifluoroacetic acid (TFA), bromophenol blue, ethanol, acetonitrile $(A C N)$ and the activator HBTU $(2-(1 \mathrm{H}-$ benzotriazole-1-yl)-1,1,3,3-tetramethylu ronium hexafluorophosphate) were achieved from Merck (Germany). The matrix $\alpha$-cyano-4-hydroxycinnamic acid (HCCA) was purchased from Sigma-Aldrich (Germany). Fmoc-GIn(Trt)-Wang Resin (extent of labeling: 0.4-0.8 $\mathrm{mmol} / \mathrm{g}$ loading) and Fmoc-Amino Acids (Fmoc-LAsn(Trt)-OH, Fmoc-L-Ala-OH, Fmoc-L-Pro-OH, Fmoc-LVal-OH, Fmoc-L-Ser(tBu)-OH, Fmoc-Gly-OH, FmocHis(Trt)-OH, Fmoc-Tyr-OH, Fmoc-L-lle-OH, Fmoc-L$\mathrm{G} \ln (\mathrm{Trt})-\mathrm{OH}, \mathrm{Fmoc}-\mathrm{L}-\mathrm{Cys}(\mathrm{Trt})-\mathrm{OH}$ ) were obtained from $\mathrm{GL}$ Biochem (Shanghai). Inorganic salts $\left(\mathrm{FeCl}_{3}\right.$ and $\left.\mathrm{CuCl}_{2}\right)$ were purchased from Merck (Darmstadt, Germany) or SigmaAldrich (USA).

Instruments. A Vibra HT analytical balance (J apan) was used to weigh the solid chemicals. The peptide samples were incubated at room temperature using an Eppendorf Thermomixer compact purchased from Germany, vortexed using a Vortex BioCote (UK) and centrifuged using a Sprout centrifuge (USA). For sample lyophilization, an ALPHA 1-2 LO Freeze Dry System was used.

MALDI-ToF MS analysis was performed on a Bruker Ultraflex MALDI ToF/ToF mass spectrometer operated in positive reflectron mode and equipped with a pulsed nitrogen UV laser ( $\lambda_{\text {max }} 337 \mathrm{~nm}$ ).

Peptide synthesis. The peptides were synthesized using the solid phase Fmoc/tBu Solid Phase Synthesis (SPPS) method. The peptide syntheses were described elsewhere $[22,23]$. In brief, the synthesis of peptides was carried out manually in a linear fashion on a Fmoc-GIn(Trt)-Wang Resin in a fritted plastic syringe. Crude peptides resulted by cleavage from the solid support using the standard TFA: TIS: $\mathrm{H}_{2} \mathrm{O}$ solution ( $95: 2.5: 2.5$ ). Following precipitation and lyophilization, the products were characterized by analytical RP-HPLC and MALDI-ToF mass spectrometry and purified by semi preparative RP-HPLC, when necessary.

Metal-peptide complexes. The solutions of peptides (8 $\mathrm{mM}$ ) and those of metal ions ( $80 \mathrm{mM})$ were prepared using milliQ-grade water. Metal complexes of NAP-like peptides were obtained by mixing the corresponding octapeptides with metal solution at $\mathrm{pH} 7$ at a 1: 10 peptide to metal ratio. Then, the resulted solutions were incubated at 350 rpm overnight at room temperature.

MS study. MALDI-ToF (Matrix-Assisted Laser Desorption Ionization Time-of-Flight) mass spectra were recorded in positive reflectron mode using a Bruker Ultraflex MALDI ToF/ToF mass spectrometer. The samples were spotted onto a 384-spot target plate of the MALDI-ToF instrument according to the dried-droplet method. Each sample and matrix solution (2,5-dihydroxybenzoic acid) were mixed on the target and allowed to dry in the ambient air. For spectra processing, the Bruker's s FlexAnalysis 3.4 software was used.

Computer programs. The exact mass (monoisotopic mass) was calculated using the application web ChemCalc [24]. Also, this application allows predicting the isotopic distribution graph and calculating peptide fragmentation.

\section{Results and discussions}

In this study, five NAP-like peptides, previously synthesized [25], were incubated over night at room temperature in aqueous medium with $\mathrm{Cu}^{2+}$ and $\mathrm{Fe}^{3+}$ ions. The interaction and their affinity of these ions toward NAPlike peptides were investigated using the MALDI ToF mass spectrometer. It is well-known that cysteine and histidine side chains are potential anchors for metal ions [26].

The characteristics of NAP-like peptides investigated in our study are presented in table 1 . In principle, these peptides have similar structures, the only modification occurring in the ${ }^{5} \mathrm{SIP}^{7}$ (Ser-lle-Pro) active center [21]. More precisely, all peptides have similar sequence, except the replacement of the fifth amino acid residue, serine, with glycine (NAPG), alanine (NAPA), histidine (NAPH) or tyrosine (NAPY).

The positive-ion matrix-assisted laser desorption/ ionization time-of-flight (MALDI ToF) mass spectra of the

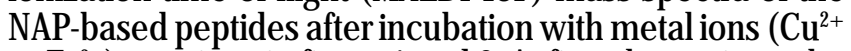
or $\mathrm{Fe}^{3+}$ ) are given in figure 1 and 2 . At first glance, it can be clearly seen that both metal ions obeyed reduction upon binding to NAP peptides. All peptides displayed signals attributed to molecular ions $[\mathrm{M}+\mathrm{H}]^{+}$and their adducts with sodium $\left([\mathrm{M}+\mathrm{Na}]^{+}\right)$and potassium $\left([\mathrm{M}+\mathrm{K}]^{+}\right)$. Another signal, assigned to deamidated peptide can be spotted in all spectra at $-16 \mathrm{~m} / \mathrm{z}\left([\mathrm{M}+\mathrm{H}-16]^{+}\right)$. As seen in table 1 , all NAP peptides contain C-terminal glutamine $(\mathrm{Q})$, which is susceptible to rearrangements that lead to peptide deamidation and pyroglutamic acid formation [27]. However, this photochemical process occurs only during the peptide ionization under the laser light source [25].

The most intense peak observed in the MALDI ToF spectra of copper incubated samples (fig. 1) was assigned to the deamidated peptides $\left([\mathrm{M}+\mathrm{H}-16]^{+}\right): \mathrm{m} / \mathrm{z} 809.6$ for NAP, $\mathrm{m} / \mathrm{z} 779.6$ for NAPG, m/z 793.6 for NAPA, m/z 859.7 for NAPH and $\mathrm{m} / \mathrm{z} 885.8$ for NAPY. The other major signals observed in the mass spectra were attributed to the $\mathrm{Cu}(\mathrm{I})$ peptide complexes even if the samples were prepared using $\mathrm{Cu}(\mathrm{II})$ salt. Hence, the peptides were capable to bind one or two $\mathrm{Cu}(\mathrm{I})$ species and to form $[\mathrm{M}+\mathrm{Cu}(\mathrm{I})]^{+}$or $[\mathrm{M}+2 \mathrm{Cu}(\mathrm{I})-\mathrm{H}]^{+}$ions. Besides the signal corresponding to

\begin{tabular}{|c|c|c|}
\hline $\begin{array}{c}\text { Peptide } \\
\text { structure }\end{array}$ & $\begin{array}{c}\text { Peptide } \\
\text { structure }\end{array}$ & $\begin{array}{c}\text { Peptide } \\
\text { code }\end{array}$ \\
\hline $\mathrm{H}_{2} \mathrm{~N}-($ Asn-Ala-Pro-Val-Ser-Ile-Pro-Gln)-COOH & NAPVSIPQ & NAP \\
$\mathrm{H}_{2} \mathrm{~N}-($ Asn-Ala-Pro-Val-Gly-Ile-Pro-Gln)-COOH & NAPVGIPQ & NAPG \\
\hline $\mathrm{H}_{2} \mathrm{~N}-($ Asn-Ala-Pro-Val-Ala-Ile-Pro-Gln)-COOH & NAPVAIPQ- & NAPA \\
\hline $\mathrm{H}_{2} \mathrm{~N}-($ Asn-Ala-Pro-Val-His-Ile-Pro-Gln)-COOH & NAPVHIPQ & NAPH \\
$\mathrm{H}_{2} \mathrm{~N}-($ Asn-Ala-Pro-Val-Tyr-Ile-Pro-Gln)-COOH & NAPVYIPQ & NAPY \\
\hline
\end{tabular}

Table 1

GENERAL STRUCTURE OF THE INVESTIGATED PEPTIDESDERIVED FROM NAP 
the complex containing the intact peptide, other peaks assigned to the $\mathrm{Cu}(\mathrm{I})$-deamidated peptide complex can be clearly spotted. The affinity of the NAP-like peptides toward $\mathrm{Cu}(\mathrm{I})$ ion can be determinate upon analyzing the intensity of the signals attributed to the metal-peptide complex, being related to the peptide composition. Thus, the highest signals assigned to the metal-peptide complexes were those of the histidine-containing NAP peptide (NAPH). For example, the most intense signal at $\mathrm{m} / \mathrm{z} 937.6$ was assigned to $[\mathrm{M}+\mathrm{Cu}(\mathrm{I})]^{+}$ion, while the second one, identified at $\mathrm{m} / \mathrm{z}$ 921.6, was attributed to [M$16+\mathrm{Cu}(\mathrm{I})]^{+}$ion. Even in the case of double metal ion complex, the histidine NAP derivative showed the highest affinity displaying two intense signal: one at $\mathrm{m} / \mathrm{z} 983.6$ assigned to $[\mathrm{M}+2 \mathrm{Cu}(\mathrm{I})-\mathrm{H}]^{+}$ion and another one at $\mathrm{m} / \mathrm{z}$ 999.5 attributed to $[\mathrm{M}-16+2 \mathrm{Cu}(\mathrm{I})-\mathrm{H}]^{+}$ion. Since histidine is known to bind strongly copper ions, being also involved in the transport of copper ions into cells, it is no surprise that NAPH peptide provided the highest affinity toward copper ions in comparison with the other NAP peptides [28].

In the case of NAP native peptide, the $[\mathrm{M}+\mathrm{Cu}(\mathrm{I})]^{+}$ion spotted at $\mathrm{m} / \mathrm{z} 887.5$ showed the highest intensity. In addition, the signals assigned to $[\mathrm{M}-16+\mathrm{Cu}(\mathrm{I})]^{+}$ion $(\mathrm{m} / \mathrm{z}$ 871.5) and $[\mathrm{M}+2 \mathrm{Cu}(\mathrm{I})-\mathrm{H}]^{+}$ion $(\mathrm{m} / \mathrm{z}$ 949.4) can be easily observed in the MS spectrum. Similar ions were also observed in the spectra of NAPG, NAPA and NAPY complexes. However, the peak intensity of $[\mathrm{M}+\mathrm{Cu}(\mathrm{I})]^{+}$ion (NAPG: $\mathrm{m} / \mathrm{z}$ 857.5; NAPA: $\mathrm{m} / \mathrm{z} 871.5$ and NAPY: $\mathrm{m} / \mathrm{z}$ 963.7) was more reduced compared to that of the molecular [M-
$16+\mathrm{H}]^{+}$ion. Therefore, there is a lower affinity of copper ion toward the modified NAP peptides with glycine, alanine and tyrosine. The other signals were assigned also to [M$16+\mathrm{Cu}(\mathrm{l})]^{+}$ion (NAPG $\mathrm{m} / \mathrm{z}$ 841.5, NAPA $\mathrm{m} / \mathrm{z}$ 855.5, NAPY $\mathrm{m} / \mathrm{z}$ 947.7), $[\mathrm{M}+2 \mathrm{Cu}(\mathrm{I})-16]^{+}$ion (NAPG $\mathrm{m} / \mathrm{z}$ 903.5, NAPA $\mathrm{m} / \mathrm{z}$ 917.4, NAPY $\mathrm{m} / \mathrm{z} 1009.7)$ and $[\mathrm{M}+2 \mathrm{Cu}(\mathrm{I})-\mathrm{H}]^{+}$ion (NAPG m/z 919.4, NAPA m/z 933.4, NAPY m/z 1025.6).

Following the interaction of $\mathrm{Fe}^{3+}$ ions with NAP peptides, the reduction of iron ions and formation of large amount of $\mathrm{Fe}^{2+}$-NAP complex was observed. As seen from figure 2, the highest peaks from the mass spectra of NAP-like peptides incubated with iron ions were assigned to $[\mathrm{M}+\mathrm{Fe}(\mathrm{II})-\mathrm{H}]^{+}$ions at $\mathrm{m} / \mathrm{z} 879.6$ (characteristic to NAP), $\mathrm{m} / \mathrm{z} 849.5$ ( NAPG), $\mathrm{m} / \mathrm{z} 863.5$ (iron complex of NAPA), $\mathrm{m} /$ z 929.6 (NAPH) and m/z 955.6 (NAPY). In addition, signals associated with [M+2Fe(II)-3H] ${ }^{+}$ion were observed in the MS spectra of all peptides: at $\mathrm{m} / \mathrm{z} 933.5$ was found NAP complex with two $\mathrm{Fe}^{2+}$ ions, at $\mathrm{m} / \mathrm{z} 903.4$ that of NAPG, at $\mathrm{m} / \mathrm{z} 917.4$ another one from NAPA, at $\mathrm{m} / \mathrm{z} 983.5$ was that of $\mathrm{NAPH}$, and at $\mathrm{m} / \mathrm{z} 1009.5$ was noticed the $[\mathrm{NAPY}+2 \mathrm{Fe}(\mathrm{II})-3 \mathrm{H}]^{+}$complex. Compared to experiments with the copper-incubated peptides, the iron ions proved to be more active and bound to a higher proportion of peptide molecules. Our results suggest an increased affinity of iron ions for NAP-like peptides. In addition to the signals associated with metal-peptide complexes, the peaks corresponding to molecular ions $[\mathrm{M}+\mathrm{H}]^{+}$, deamidated peptides $[\mathrm{M}-16+\mathrm{H}]^{+}$and their adducts with sodium $\left([\mathrm{M}+\mathrm{Na}]^{+}\right)$and potassium $\left([\mathrm{M}+\mathrm{K}]^{+}\right)$can be spotted in all spectra.

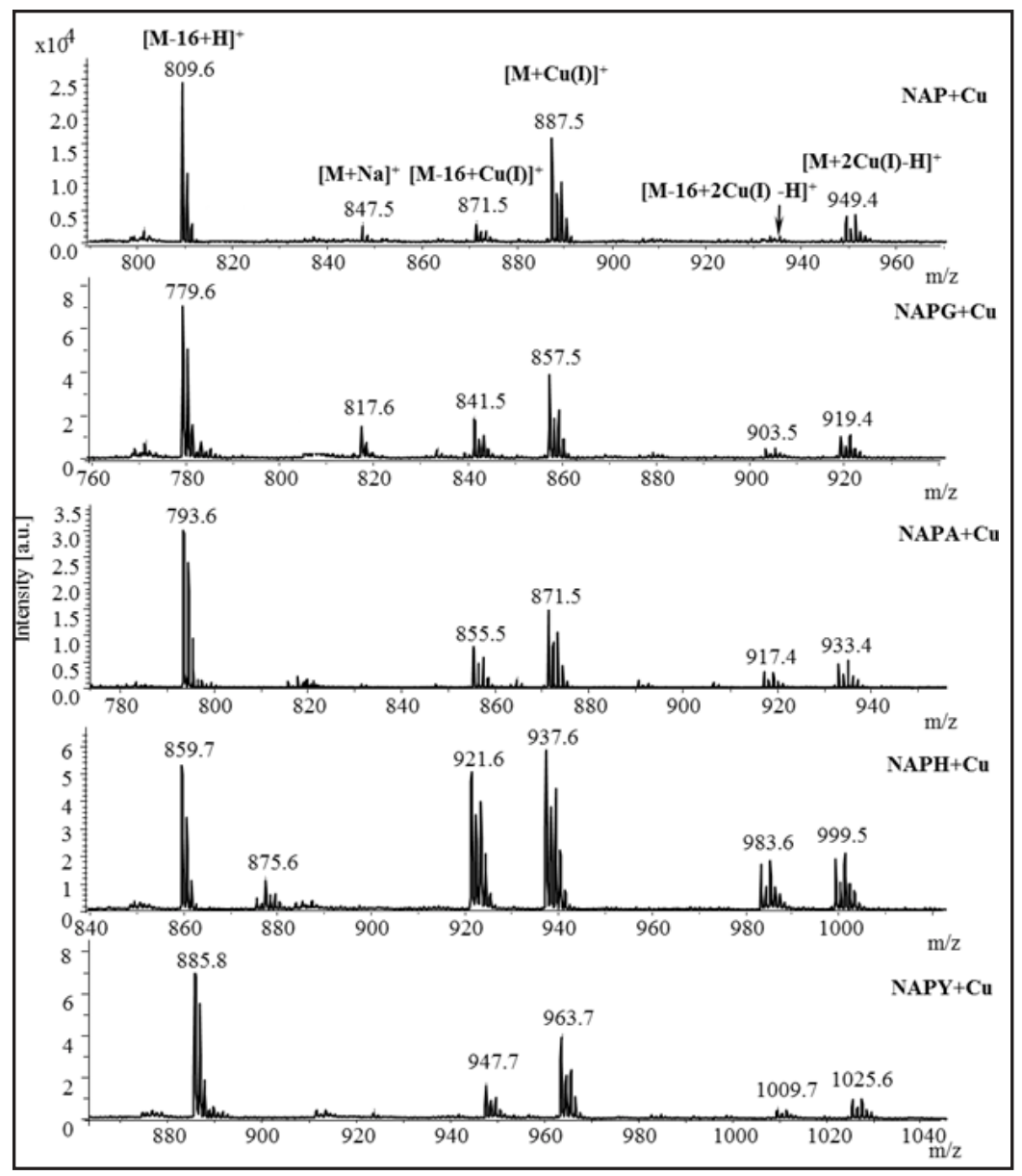

Fig. 1. MALDI-ToF MS spectra of the NAP-like peptides in the presence of copper ions ata 1: 10 peptide: metal ratio ( $4 \mathrm{mM}$ peptide and $40 \mathrm{mM}$ copperions) 


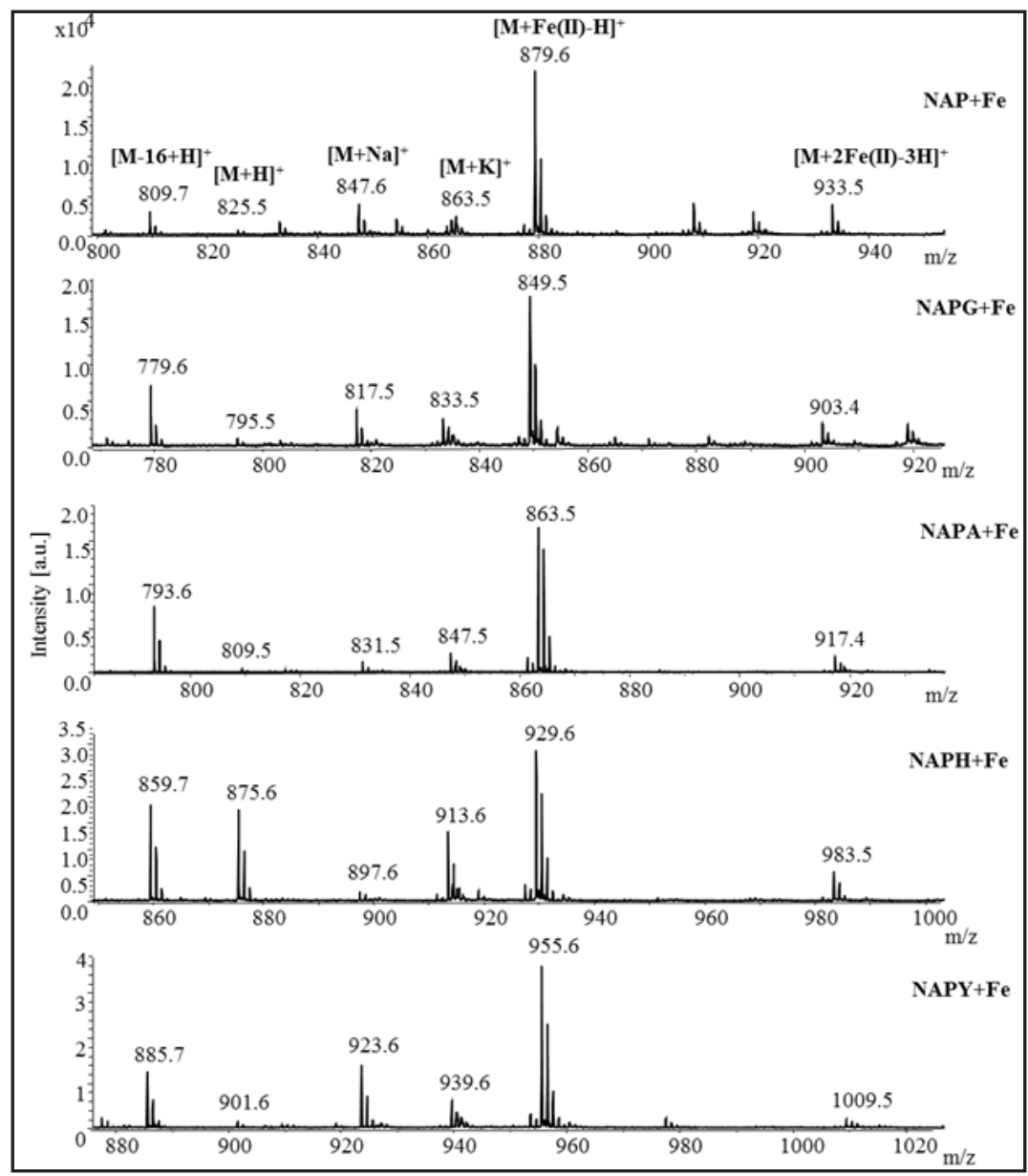

Fig. 2.MALDI-ToF MS spectra of the NAPlike peptides in the presence of iron ions at a 1: 10 peptide to metal ratio ( $4 \mathrm{mM}$ peptide and $40 \mathrm{mM}$ iron ions)

However, their intensity was lower compared to that associated to metal-peptide complexes. The highest percentage of free peptide was observed in the NAPH spectra, were signals associated to peptides $[\mathrm{M}-16+\mathrm{H}]^{+}$, $[\mathrm{M}+\mathrm{H}]^{+}$and $[\mathrm{M}+\mathrm{K}]^{+}$ions were found at $\mathrm{m} / \mathrm{z} 859.7, \mathrm{~m} / \mathrm{z}$ 875.6 and $\mathrm{m} / \mathrm{z}$ 913.6. The spectra of tyrosine-modified peptide, NAPY, showed average signals at $\mathrm{m} / \mathrm{z} 885.7, \mathrm{~m} / \mathrm{z}$ 923.6 and $\mathrm{m} / \mathrm{z}$ 939.6, being assigned to $[\mathrm{M}-16+\mathrm{H}]^{+}$, $[\mathrm{M}+\mathrm{Na}]^{+}$and $[\mathrm{M}+\mathrm{K}]^{+}$ions, respectively. Signals assigned to $[\mathrm{M}-16+\mathrm{H}]^{+}$ions were observed in the spectra of NAP (at $\mathrm{m} / \mathrm{z}$ 809.7), NAPG (at $\mathrm{m} / \mathrm{z} 779.6$ ) and NAPA (at $\mathrm{m} / \mathrm{z}$ 793.6). The sodium and potassium adducts of peptides were also seen in the MS spectra at $\mathrm{m} / \mathrm{z} 847.6$ for NAP, $\mathrm{m} /$ z 817.5 for NAPG and $\mathrm{m} / \mathrm{z} 831.5$ for NAPA ([M+Na]+ ion) and at $m / z 863.5$ (with NAP), $m / z 833.5$ (bound to NAPG) and $\mathrm{m} / \mathrm{z} 847.5$ (adduct of NAPA), corresponding to $[\mathrm{M}+\mathrm{K}]^{+}$ ion.

Table 2 shows the theoretical and experimental values of the main peaks in the mass spectra. The experimental $\mathrm{m} / \mathrm{z}$ values displayed by the MALDI ToF mass spectrometer were in best agreement with theoretical data obtained using the ChemCalc program.

Figure 3 and 4 show the experimental isotopic distribution of the copper-peptide and iron-peptide complexes following the MS analysis of the samples. The theoretical distribution of the $[\mathrm{M}+\mathrm{Cu}(\mathrm{I})]^{+}$ion and $[\mathrm{M}+\mathrm{Fe}(\mathrm{II})-\mathrm{H}]^{+}$was similar with that experimentally determined.

In this study we showed that two noxious metal ions can bind to anti-amyloid peptides. Heavy metals, including copper and iron, are environmental contaminants that cannot be degraded or destroyed [10,29]. Their biological effect differs from that of organic pollutants such as dinitrophenols [30,31]. Decontamination of dinitrophenol derivatives can be done by yeast suspensions, since they can live anaerobically [32, 33]. Thus, heavy metal altered metal homeostasis can be one of the factors causing many pathologies. In addition, redox active metals carry prooxidant properties that induce oxidative stress by ROS. These reactive oxygen species causes protein, DNA or phospholipids oxidations. Previously, we investigated the interaction of heavy metal ions with $A \beta$ peptides associated with Alzheimer disease using glycyl-Ltryptophan, which interact with $\mathrm{Fe}^{3+}$ and $\mathrm{Cu}^{2+}$ ions that decrease its fluorescence intensity at $350 \mathrm{~nm}$ [7].

In this research, we performed mass spectrometric measurements to investigate heavy metal binding to peptides and proteins, since this technique is an important analytical approach utilized for quantitative and qualitative determination, structure and chemical properties elucidation [34, 35]. Due to its wide range of applications, MS has become an indispensable tool for analyzing biomolecules [36]. Proteomics research took advantage of the development of soft ionization techniques such as electrospray ionization (ESI) and matrix assisted laser desorption/ionization (MALDI) capable of easily transforming biomolecules into ions [37]. MALDI mass spectrometry implies the use of a matrix capable of absorbing the laser energy and creates ions from large molecules with minimal fragmentation. Thus, MALDI technique is capable to ionize complexes while using less solvent than electrospray ionization techniques [38]. The MALDI ionization is commonly used for the analysis of high molecular weight biological compounds, buthas also been used for transition metal complexes analysis [39].

We investigated here NAP analogs containing glycine, alanine, histidine and tyrosine residues instead serine in the native NAP sequence, since cysteine is well-known ligand for copper and iron [22, 26, 41]. 
Table 2

MOLECULAR WEIGHT OF THE PEPTIDES, ASEXPERIMENTALLY DETERMINED WITH A MALDITOF INSTRUMENT OR CALCULATED WITH CHEMCALC SOFT [24]

\begin{tabular}{|c|c|c|c|}
\hline Peptide & Molecular Ion & Theoretical $(m / z)$ & Expenimental $(m / z)^{-}$ \\
\hline \multirow{10}{*}{$\begin{array}{c}\text { NAP } \\
\left(\mathrm{H}_{2} \mathrm{~N} \text {-NAPVSIPQ-COOH) }\right. \\
\mathrm{C}_{36} \mathrm{H}_{60} \mathrm{~N}_{10} \mathrm{O}_{12}\end{array}$} & {$[\mathrm{M}-16+\mathrm{H}]^{+}$} & 809.4 & 809.6 \\
\hline & {$[\mathrm{M}+\mathrm{H}]^{+}$} & 825.4 & 825.5 \\
\hline & {$[\mathrm{M}+\mathrm{Na}]^{+}$} & 847.4 & 847.5 \\
\hline & {$[\mathrm{M}+\mathrm{K}]^{+}$} & 863.4 & 863.5 \\
\hline & {$[\mathrm{M}-16+\mathrm{Cu}(\mathrm{I})]^{+}$} & 871.4 & 871.5 \\
\hline & {$[\mathrm{M}+\mathrm{Cu}(\mathrm{I})]^{+}$} & 887.4 & 887.5 \\
\hline & {$[\mathrm{M}-16+2 \mathrm{Cu}(\mathrm{I})-\mathrm{H}]^{+}$} & 933.3 & - \\
\hline & {$[\mathrm{M}+2 \mathrm{Cu}(\mathrm{I})-\mathrm{H}]^{+}$} & 949.3 & 949.4 \\
\hline & {$[\mathrm{M}+\mathrm{Fe}(\mathrm{II})-\mathrm{H}]^{+}$} & 879.4 & 879.6 \\
\hline & {$[\mathrm{M}+2 \mathrm{Fe} \text { (II)-3H] }]^{+}$} & 933.3 & 933.5 \\
\hline \multirow{10}{*}{$\begin{array}{c}\text { NAPG } \\
\left(\mathrm{H}_{2} \mathrm{~N}-\mathrm{NAPVGIPQ}-\mathrm{COOH}\right) \\
\mathrm{C}_{3 \mathrm{~s}} \mathrm{H}_{53} \mathrm{~N}_{10} \mathrm{O}_{11}\end{array}$} & {$[\mathrm{M}-16+\mathrm{H}]^{+}$} & 779.4 & 779.6 \\
\hline & {$[\mathrm{M}+\mathrm{H}]^{+}$} & 795.4 & 795.5 \\
\hline & {$[\mathrm{M}+\mathrm{Na}]^{+}$} & 817.4 & 817.6 \\
\hline & {$[\mathrm{M}+\mathrm{K}]^{+}$} & 833.4 & 833.5 \\
\hline & {$[\mathrm{M}-16+\mathrm{Cu}(\mathrm{I})]^{+}$} & 841.3 & 841.5 \\
\hline & {$[\mathrm{M}+\mathrm{Cu}(\mathrm{I})]^{+}$} & 857.4 & 857.5 \\
\hline & {$[\mathrm{M}-16+2 \mathrm{Cu}(\mathrm{I})-\mathrm{H}]^{+}$} & 903.3 & 903.5 \\
\hline & {$[\mathrm{M}+2 \mathrm{Cu}(\mathrm{I})-\mathrm{H}]^{+}$} & 919.3 & 919.4 \\
\hline & {$[\mathrm{M}+\mathrm{Fe}(\mathrm{II})-\mathrm{H}]^{+}$} & 849.4 & 849.5 \\
\hline & {$[\mathrm{M}+2 \mathrm{Fe} \text { (II)- } 3 \mathrm{H}]^{+}$} & 903.3 & 903.4 \\
\hline \multirow{10}{*}{$\begin{array}{c}\text { NAPA } \\
\left(\mathrm{H}_{2} \mathrm{~N}-\mathrm{NAPVAIPQ}-\mathrm{COOH}\right) \\
\mathrm{C}_{36} \mathrm{H}_{50} \mathrm{~N}_{10} \mathrm{O}_{11}\end{array}$} & {$[\mathrm{M}-16+\mathrm{H}]^{+}$} & 793.4 & 793.6 \\
\hline & {$[\mathrm{M}+\mathrm{H}]^{+}$} & 809.5 & 809.5 \\
\hline & {$[\mathrm{M}+\mathrm{Na}]^{+}$} & 831.4 & 831.5 \\
\hline & {$[\mathrm{M}+\mathrm{K}]^{+}$} & 847.4 & 847.5 \\
\hline & {$[\mathrm{M}-16+\mathrm{Cu}(\mathrm{I})]^{+}$} & 855.4 & 855.5 \\
\hline & {$[\mathrm{M}+\mathrm{Cu}(\mathrm{I})]^{+}$} & 871.4 & 871.5 \\
\hline & {$[\mathrm{M}-16+2 \mathrm{Cu}(\mathrm{I})-\mathrm{H}]^{+}$} & 917.3 & 917.4 \\
\hline & {$[\mathrm{M}+2 \mathrm{Cu}(\mathrm{I})-\mathrm{H}]^{+}$} & 933.3 & 933.4 \\
\hline & {$[\mathrm{M}+\mathrm{Fe}(\mathrm{II})-\mathrm{H}]^{+}$} & 863.5 & 863.4 \\
\hline & {$[\mathrm{M}+2 \mathrm{Fe}(\mathrm{II})-3 \mathrm{H}]^{+}$} & 917.3 & 917.4 \\
\hline \multirow{10}{*}{$\begin{array}{c}\text { NAPH } \\
\left(\mathrm{H}_{2} \mathrm{~N}-\mathrm{NAPVHIPQ}-\mathrm{COOH}\right) \\
\mathrm{C}_{39} \mathrm{H}_{62} \mathrm{~N}_{12} \mathrm{O}_{11}\end{array}$} & {$[\mathrm{M}-16+\mathrm{H}]^{+}$} & 859.5 & 859.7 \\
\hline & {$[\mathrm{M}+\mathrm{H}]^{+}$} & 875.5 & 875.6 \\
\hline & {$[\mathrm{M}+\mathrm{Na}]^{+}$} & 897.5 & 897.6 \\
\hline & {$[\mathrm{M}+\mathrm{K}]^{+}$} & 913.4 & 913.6 \\
\hline & {$[\mathrm{M}-16+\mathrm{Cu}(\mathrm{I})]^{+}$} & 921.4 & 921.6 \\
\hline & {$[\mathrm{M}+\mathrm{Cu}(\mathrm{I})]^{+}$} & 937.4 & 937.6 \\
\hline & {$[\mathrm{M}-16+2 \mathrm{Cu}(\mathrm{I})-\mathrm{H}]^{+}$} & 983.3 & 983.6 \\
\hline & {$[\mathrm{M}+2 \mathrm{Cu}(\mathrm{I})-\mathrm{H}]^{+}$} & 999.3 & 999.5 \\
\hline & {$[\mathrm{M}+\mathrm{Fe}(\mathrm{II})-\mathrm{H}]^{+}$} & 929.4 & 929.6 \\
\hline & {$[\mathrm{M}+2 \mathrm{Fe} \text { (II)-3H }]^{+}$} & 983.3 & 983.5 \\
\hline \multirow{10}{*}{$\begin{array}{c}\text { NAPY } \\
\left(\mathrm{H}_{2} \mathrm{~N}-\mathrm{NAPVYIPQ}-\mathrm{COOH}\right) \\
\mathrm{C}_{42} \mathrm{H}_{64} \mathrm{~N}_{10} \mathrm{O}_{12}\end{array}$} & {$[\mathrm{M}-16+\mathrm{H}]^{+}$} & 885.5 & 885.7 \\
\hline & {$[\mathrm{M}+\mathrm{H}]^{+}$} & 901.5 & 901.6 \\
\hline & {$[\mathrm{M}+\mathrm{Na}]^{+}$} & 923.5 & 923.6 \\
\hline & {$[\mathrm{M}+\mathrm{K}]^{+}$} & 939.4 & 939.6 \\
\hline & {$[\mathrm{M}-16+\mathrm{Cu}(\mathrm{I})]^{+}$} & 947.4 & 947.7 \\
\hline & {$[\mathrm{M}+\mathrm{Cu}(\mathrm{I})]^{+}$} & 963.4 & 963.7 \\
\hline & {$[\mathrm{M}-16+2 \mathrm{Cu}(\mathrm{I})-\mathrm{H}]^{+}$} & 1009.3 & 1009.7 \\
\hline & {$[\mathrm{M}+2 \mathrm{Cu}(\mathrm{I})-\mathrm{H}]^{+}$} & 1025.3 & 1025.6 \\
\hline & {$[\mathrm{M}+\mathrm{Fe}(\mathrm{II})-\mathrm{H}]^{+}$} & 955.4 & 955.6 \\
\hline & {$[\mathrm{M}+2 \mathrm{Fe}(\mathrm{II})-3 \mathrm{H}]^{+}$} & 1009.3 & 1009.5 \\
\hline
\end{tabular}

-(-) not present in the MALDI-ToF mass spectra

On using ESI ion-trap MS measurements, iron binding to $A \beta(1-40)$ peptide associated with Alzheimer disease was demonstrated [42]. Our results using MALDI ToF MS have thus confirmed $\mathrm{Fe}^{2+}$ ion binding to peptides, and not $\mathrm{Fe}^{3+}$ ion. It is therefore possible that $\mathrm{Fe}^{2+}$ ion, but $\mathrm{Fe}^{3+}$ ion, to bind to $A \beta(1-40)$, which means that further research is necessary to confirm this hypothesis. Besides, ESI-MS results seem to be in good agrement with those obtained by MALDI-ToF MS [41, 43].
Our studies on copper and iron interaction with neuropeptides are in line with the literature data [44]. Copper binding to peptides and proteins was also studied in order to find new methods for protein determination [45]. Indeed, protein determination is still a difficult task and novel assays were proposed [46, 47]. However, the main result of our study is redox metal binding to NAP-like peptides only under their reduced form. 

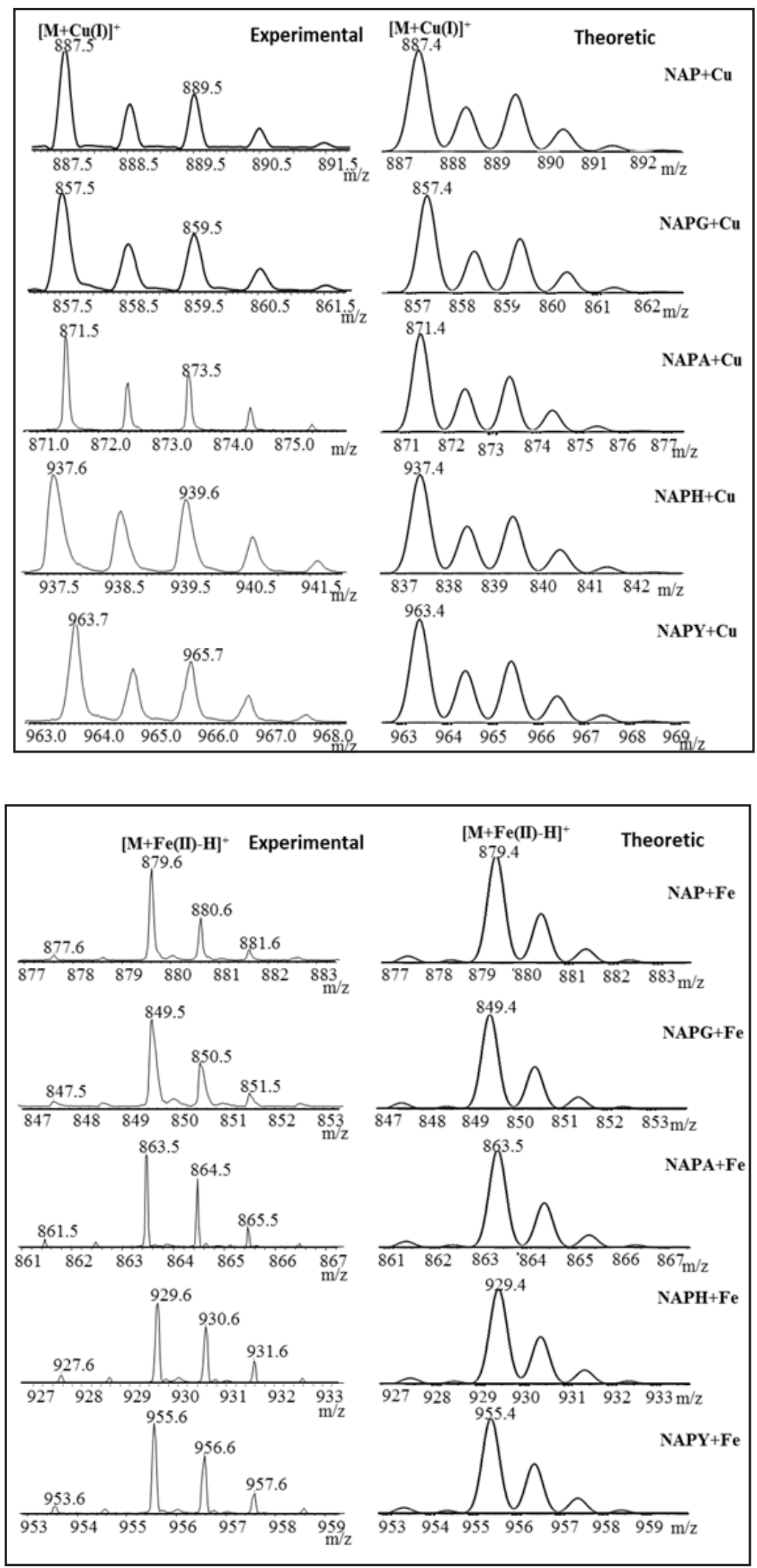

Fig. 3. The experimentally determined isotopic distribution of copper-peptide complexes $\left([\mathrm{M}+\mathrm{Cu}(\mathrm{l})]^{+}\right)(\mathrm{left})$ and the theoreticallycalculated ones (right)
Fig. 4.The experimentally obtained isotopic distribution of iron-peptide complexes ([M+Fe(II)-H $]^{+}$) (left) and the theoretical ones (right)

\section{Conclusions}

In this work we have demonstrated the reduction of $\mathrm{Fe}^{3+}$ and $\mathrm{Cu}^{2+}$ ions to $\mathrm{Fe}^{2+}$ and $\mathrm{Cu}^{+}$followed by their binding to some newly synthesized NAP-like peptides. This ubiquitous phenomenon may suggest a double protective role for NAP peptide: i) metal scavenger and ii) potential therapeutic agent against the ROS metal-mediated cascade. Since the Fenton oxidation chemistry is a general feature for all neurodegenerative disorders, chelation therapy constitutes a possible treatment against heavy metal accumulation. Our results identify native NAP and its glycine (NAPG), alanine (NAPA), histidine (NAPH) and tyrosine (NAPY) modified peptides as therapeutic strategies for metal chelating. However, different peptides bind differently iron and copper ions. Further research is needed to understand the complex relationship of NAPlike peptides and metal ions involved in Alzheimer disease or other neurodegenerative pathologies. 
Acknowledgments:The financial support from the (UEFISCDI Bucharest, PN-III-P4-ID-PCE-2016-0376, Contract 56/2017) is gratefully acknowledged.

\section{References}

1.WANG, J., PANTOPOULOS, K., Biochem. J ., 434, no. 3, 2011, p. 365381.

2.BEARD, J.L., CONNOR, J.R.,Annu.Rev. Nutr., 23, no.1, 2003, p.41-58. 3.PENTA, M.M., LEE, J., THIELE, D.J ., J. Nutr., 129, no. 7, 1999, p. 12511260.

4.RIVERA-MANCIA, S., PEREZ-NERI, I., RIOS C., TRISTAN-LOPEZ, L., RIVERA-ESPINOSA, L., MONTES, S., Chem. Biol. Interact., 186, no. 2, 2010, p. 184-199.

5.YOUDIM, M.B.H., FRIDKIN, M., ZHENG, H., Mech. Ageing Dev., 126, no. 2, 2005, p. 317-326.

6.ROUAULT, T. A. Pediatr. Neurol., 25, no. 2, 2001, p. 130-137.

7.BANCILA, S., PINTILIE, O., GRADINARU, R., SANDU, I., DROCHIOIU, G., BALAN, G.G., Rev. Chim. (Bucharest), 67, no. 5, 2016, p. 974-977. 8.CARAUSU, E.M., CHECHERITA, L.E., STAMATIN, O., ALBU, A., Rev. Chim. (Bucharest), 67, no. 9, 2016, p. 1832-1837.

9.MARTÍNEZ-CAYUELA, M., Biochimie, 77, no. 3, 1995, p. 147-161. 10.NECULA, R., GILLE, E., DIRTU, A.C., SANDU, I., GRADINARU, V.R., PETCU, A., DROCHIOIU, G., Rev. Chim. (Bucharest), 69, no. 7, 2018, p. 1682-1686.

11.AGAR, J., DURHAM, H., Amyotroph. Lat. Scl. Motor Neuron Disord., 4, no. 4, 2003, p. 232-242.

12.PETRE, B.-A., YOUHNOVSKI, N., LUKKARI, J., WEBER, R., PRZYBYLSKI, M., Eur. J. Mass Spectrom., 11, no. 5, 2005, p. 513-518. 13.BAIG, M.H., AHMAD, K., RABBANI, G., CHOI, I., Front. Aging Neurosci., 10, art. 21, 2018, p. 1-6.

14.DUMITRU, G., ABIDAR, S., NHIRI, M., HRITCU, L., BOIANGIU, R.S., SANDU, I., TODIRASCU-CIORNEA, E., Rev. Chim. (Bucharest), 67, no. 12, 2018, p. 3545-3548.

15.POSTU, P.A., NOUMEDEM, J.A.K., CIOANCA, O., HANCIANU, M., MIHASAN, M., CIORPAC, M., GORGAN, D.L., PETRE, B.A., HRITCU, L., J. Cell. Mol. Med., 22, no. 1, 2018, p. 111-122.

16.AVRAM, M., STROESCU, M., STOICA-GUZUN, A., FLOAREA, O., DOBRE, T. Rev. Chim. (Bucharest), 66, no. 1, 2015, p. 79-82. 17.POPA IORDANESCU, I., POPA, O., BABEANU, N., NITA, S, PARASCHIV, I., DOBRE, N., IONICA I., Rev. Chim. (Bucharest), 66, no. 5, 2015, p. 634-636.

18.DUMONT, M., BEAL, M.F., Free Radic. Biol. Med., 51, no. 5, 2011, p. $1014-1026$

19.MANDEL, S., RECHAVI, G., GOZES, I., Dev. Biol., 303, no. 2, 2007, 814-824

20.GOZES, I., MORIMOTO, B.H., TIONG, J., FOX, A., SUTHERLAND, K., DANGOOR, D., HOLSER-COCHAV, M., VERED, K., NEWTON, P., AISEN, P.S., MATSUOKA, Y., VAN DYCK, C.H., THAL, L., CNS Drug Rev., 11, no. 4, 2006, p. 353-368.

21.0Z, S., KAPITANSKY, O., IVASHCO-PACHIMA, Y., MALISHKEVICH, A., GILADI, E., SKALKA, N., ROSIN-ARBESFELD, R., MITTELMAN, L., SEGEV, O., HIRSCH, J .A., GOZES, I., Mol. Psychiatry, 19, no. 10, 2014, p. $1115-1124$.

22.CIOBANU, C.I., STEFANESCU, R., NICULAUA, M., TESLARU, T., GRADINARU, R., DROCHIOIU, G., Eur. J. Mass Spectrom., 22, no. 2, 2016, p. 97-104.
23.LUPAESCU, A.V., JURESCHI, M., CIOBANU, C.I., ION L., ZBANCIOC, G., PETRE, B.A., DROCHIOIU, G., Int. J. Pept. Res. Ther., 25, no. 1, 2018, p. 303-309.

24.PATINY, L., BOREL, A., J. Chem. Inf. Model., 53, no. 5, 2013, p. 1223-1228.

25.LUPAESCU, A.V., CIOBANU, C.I., HUMELNICU, I., PETRE, B.A., MURARIU, M., DROCHIOIU, G., Rev. Roum. Chim., 2019, in press. 26.MURARIU, M., POPA, K., DRAGAN, E.S., DROCHIOIU, G., Rev. Roum. Chim., 54, no. 9, 2009, p. 741-747.

27.CHEN, X., DROGARIS, P., BERN, M., J. Proteome Res., 9, no. 6, 2010, p. 3270-3279.

28.VENELINOV, T., ARPADJ AN, S., KARADJ OVA, I., BEATTIE, J., Acta Pharm., 56, 2006, p. 105-112.

29.TODIRASCU-CIORNEA, E., DUMITRU, G., ZAHARIA, M., DROCHIOIU, G., SANDU, I., Rev. Chim. (Bucharest), 69, no. 2, 2018, p. 449-452.

30.PINTILIE, O., ANDRIES, C., COSMA, A., ZAHARIA, M., DROCHIOIU, G., VASILACHE, V., SANDU, ION., Rev. Chim. (Bucharest), 66, no. 9, 2015, p. 1321-1326.

31.DUMITRAS-HUTANU, C.A., PUI, A., JURCOANE, S., RUSU, E., DROCHIOIU, G., Rom. Biotechnol. Lett., 14, no. 6, 2009, p. 4893-4899. 32.PINTILIE, O., ZAHARIA, M., COSMA, A., MURARIU, M., GRADINARU, R., BALAN, G.G., DROCHIOIU, G., SANDU, I., Rev. Chim. (Bucharest), 67, no. 2, 2016, p. 375-377.

33.PINTILIE, O. ZAHARIA, M., COSMA, A., MURARIU, M., COZMA, D., DROCHIOIU, G., Rev. Chim. (Bucharest), 67, no. 11, 2016, p. 21932197.

34.SCHLOSSER, G., STEFANESCU, R., PRZYBYLSKI, M., MURARIU, M., HUDECZ, F., DROCHIOIU, G., Eur. J. Mass Spectrom., 13, no. 5, 2007, p. 331-337.

35.MURARIU, M., DRAGAN, E.S., DROCHIOIU, G., Int. J. Pept. Res. Ther., 15, no. 4, 2009, p. 303-311.

36.VERTES, A., VEKEY, K., Medical applications of mass spectrometry. Elsevier, 2011, p. 3-6.

37.EL-ANEED, A., COHEN, A., BANOUB, J., Appl. Spectrosc. Rev., 44, no. 3, 2009, p. 210-230.

38.ZENOBI, R., KNOCHENMUSS, R., Mass Spectrom. Rev., 17, no. 5 , 1998, p. 337-366.

39.PETKOVIC, M., PETROVIC, B., SAVIC, J., BUGARCIC, Z.D., DIMITRICMARKOVIC, J., MOMIC, T., VASIC, V., Int. J. Mass Spectrom., 290, no. 1, 2010, p. 39-46.

40.MURARIU, M., DRAGAN, E.S., DROCHIOIU, G., Biomacromolecules, 8, no. 12, 2007, p. 3836-3841.

41.DROCHIOIU, G., Eur. J. Mass Spectrom., 15, no. 5, 2009, p. 651-659. 42.MURARIU, M., ION, L., CIOBANU, C.I., Rev. Roum. Chim., 62, no. 3, 2017, p. 277-289.

43.MADSEN, E., GITLIN, J.D., Annu. Rev. Neurosci., 30, no. 1, 2007, p. 317-337.

44.DROCHIOIU, G., DAMOC, N., PRZYBYLSKI, M., Talanta, 69, no. 3, 2006, p. 556-564.

45.DROCHIOIU, G., CIOBANU, C.I., BANCILA, S., ION, L., PETRE, B.A., ANDRIES, C., GRADINARU, R.V., MURARIU, M., Ultrason. Sonochem., 29, 2016, p. 93-103.

46.DROCHIOIU, G., MURARIU, M., MANGALAGIU, I., DRUTA, I., Talanta, 56, no. 3, 2002, p. 425-433.

$\overline{\text { Manuscript received;22.11.2018 }}$ 